\title{
SUFI EDUCATIONAL TENETS: Practical Encounters of Sufi Teachings and Educational Curricula
}

\author{
Subaidi \\ Universitas Nahdlatul Ulama Jepara \\ zubaidimalhud@yahoo.co.id
}

\begin{abstract}
This research on concept of Sufism by"Abdul Wahab as-Sya'rani studies about the education components which covers: the aspects of purpose and teaching material, the aspects of teacher and students, the aspects of method and strategy in Sufism Education, as well as the relevance of Sufism education by as-Sya'rani with the development of character building. The objectives of this research are: a) To describe what the objectives and teaching materials in Sufism by as-Sya'rani are; b) To describe how the position of the teacher and students in Sufism education by as-Sya'rani is; c) To describe what the method in Sufism education by as-Sya'rani is; d) To describe how relevant the Sufism by as-Sya'rani with the development of character building is. This qualitative research uses hermeneutic approach. The analysis method used in this research is content analysis with the descriptive features. The writer uses the hermeneutic approach because he efforts to describe the facts gained from text containing as-Sya'rani's thoughts on Sufism education and performs the perception towards the sense of texts in effort to be possibly close to understand the idea of asSya'rani's Sufism education.
\end{abstract}

Keywords. concept, education, Sufism, character

\section{A. Introduction}

$\mathrm{N}$

owadays crisis that has been suffered by the adult man is multi-dimension crisis in every aspect of life, such as the dimension of materialism life hegemony and positivism. Both dimensions have led the mankind on the destruction of esoteric dimension. The crisis, according to Kartanegara, ${ }^{1}$ will cause "disorientation" towards the modern people. Besides, more and more modern people are far from the vision of divinity can cause the symptoms of psychological and spiritual problem like "the spiritual emptiness". The impact is that we can find more people overburdened with being stress, restless, confused, and nervous; due to the loss of

\footnotetext{
${ }^{1}$ Mulyadhi Kartanegara, Menyelami Lubuk Tasawuf(Bandung: Erlangga, 2006), 266.
} 
strong guidelines of life, that is centered on the existence (of God). ${ }^{2}$ The advance of science relying on the ratio, up to the particular limits, will be able to break the fortress of idealism value and more directives to the rationalism, pragmatism, and relativism.

Therefore, in order that men don't suffer from the spiritual emptiness, the Islamic education, especially Sufism education, should be formulated in order to educated the men who are willing to purify their soul that proceed to the awareness of divinity, in that the Sufism education is cultivating of in-heart love to Allah, calling out for His riḍa in every utterance, deed, attitude, and behavior, then keeping away from what makes Allah angry.

There are many things that make people worried about when observing the process and result of education all this time. The education should produce the superior and prestigious person, but in fact it is far from the expectation. The anomaly ${ }^{4}$ is precisely performed much by "the educated people". There are many morality cases of teenage and children such as free sex, the engaging students on gang fight in the big cities, the phenomenon of under-aged students as procures at Surabaya, the destruction towards the school facilities and disobeying the teachers when they don't pass the exam at Vocational/Senior High School. It so worrying that there will not be collective action to change the on- going education model.

The acute conflicts in the political escalation on each succession of political leader and the election of regent/governor having been taking place in all Indonesian territory cause more and more people's poverty and sufferings. The needy and the victims of disaster are increasingly handled when the party elite and the religion characters are trapped in the battle of materialism power. The capitalism and political greediness which tend to be corruptive are born due to the behavior of reaching material minded. ${ }^{5}$

The above facts are parts of Secularism, as well as Islamic education that tend to be materialism. Therefore, the researcher is trying to give the space for the presence of new idea; that is the Sufism education. Regarding the lack of divinity aspect in education process along with its science, people need new nuance through Sufism education. So, many researchers are interested in the thought of phenomenal figure in tassawuf: 'Abdul Wahab al-Sya'râni.

\footnotetext{
${ }^{2}$ Azra, Esei-esei intelektual Muslim dan pendidikan Islam, (Jakarta: Logos Wacana Ilmu, 1999), 101.

${ }^{3}$ The term of anomaly in daily life means an oddness, weird, or deviation from the usual thing or normal/majority situation, John Echols, Kamus Inggris, (Jakarta: Gramedia, 1995), 30.

${ }^{4}$ Thomas S. Kuhn, Peran Paradigma dalam Revolusi Sains (Bandung: Remadja Karya, 1989), 52.

${ }^{5}$ Amir al-Najjar, Psikoterapi Sufistik dalam Kehidupan Modern (Bandung: Hikmah, 2004), 66.
} 


\section{B. Bibliography of: 'Abdul Wahab al-Sya'râni.}

Al-Sya'rāni is a tasawuf Islamic scholar, born in Ramadan $27^{\text {th }}, 900 \mathrm{H} / 1492$ at the region of Qalqalandah, in a village of his grandfather. After 40 days of his birth day he moved to his father village, an irrigation area of Abì Sya'rah where he was coroneted. Since, he was known as al-Sya'rāni6. The ancestor of five generation backward was Musa Abu Imran, one of Sultan Telmesen's sons, who ever governed the territory of North Africa. Musa Abu Amran became the follower of syekh Abi Madyan Syu'aīb atTilmīsāni, a figure of Sufism syadhiliah who delegated him as one of missionary expedition to the deep Egypt up to die (707 H/Islamic Calender). One of Musa's grandchild (named Ahmad) was a religious man and well-known as a holly person though he was illiteracy. Finally he moved, lived and inherited for generations at Syaqiyat Abū Sya'rā village, Minufiyah provice and passed away in $828 \mathrm{H}$. One of Ahmad grandchild (also named "Ahmad", the father of al-Sya'rāni ) was also well-known as a religious man. ${ }^{7}$

The most important and influential guide of al-Sya'rāni was Syekh 'Ali alKhawwās (who died on 979 H/1352-3). ${ }^{8}$ He passed away on 12 Jumādil Awal 973 H/5 Desember 1565 and laid to rest on one of special

Guru tasawuf pembimbing spiritual yang terpenting dan paling berpengaruh bagi al-Sya'rāni adalah Syekh 'Ali al-Khawwās (wafat 979 H/1352-3). ${ }^{9}$ He passed away on Jumadil Awal $973 \mathrm{H} /$ December $5^{\text {th }}, 1565$ and was laid to rest in a location that was specially built for him. Since 1177 on Islamic calendar, his name was perpetuated as a mosque name near the location he was laid in rest. During his life he focused on the religious activities (Bosworth, 1997: 316).

Al-Sya'rāni was born in the milieu of religious and educated family so he had a chance to have education at the early age. He confessed that he had already known by heart all Quran verses since he was 7 years old. The indication that he would be a great scholar came since he was young. When his family moved to Cairo, his father brought him to visit syekh Jalāl ad-Dīn as-Suyūtī, to beg his prayer and gain sheikh's certificate. After having known his perspicacity, as-Suyūtī gave him certificate to teach both holly book and hadiths, whereas al-Sya'rāni was still 10 years old.10

\footnotetext{
${ }^{6}$ Abdul Wahab al-Sya'rāni, Al-Anwar Al-Qudsiyah Fi Ma'rifati as-Șūfiyyah (Bairut: al-Maktabah al-Ilmiyah, 1992), 4.

${ }^{7}$ Taufiq Tanwil, At-Tasawuf Fi Misr Aban Al-Asr Al-Uśmāni (Kairo: al-Hai'a al-Misriyya, n.d.), 16.

${ }^{8}$ al-Sya'rāni, Al-Anwar Al-Qudsiyah Fi Ma'rifati as-Șūfiyyah, 5-6.

${ }^{9}$ Ibid.

${ }^{10}$ Clifford Edmund Bosworth, The Encyclopaedia of Islam (Leiden: Brill, 1997), 317.
}

Teosofia: Indonesian Journal of Islamic Mysticism, Volume 5, Number 1, 2016 
One day al-Sya'rāni suffered from spiritual crisis and inner shock. Then, in order to get inner tranquility, Ali al-Khawwas suggest that he should not be satisfied with any knowledge he already obtained and scientific work he had produced. He suggested that al-Sya'rāni should completely stop learning the knowledge he had been dealing with and start performing suluk seriously under the guidance of a sheikh (a Sufism teacher). The teacher would guide him a "direct way" to Allah. After a deep and long contemplation al-Sya'rāni finally decided to grant the advice. ${ }^{11}$

Ali al-Khawwās asked him to continuously recite dhikir to Allah in order that he could forget all his knowledge quickly, and indeed he also sincerely obeyed the order. Beside he also should perform a serial of procedure to manage the soul (riyādah) as well as some heavier ones like doing uzlah, intensifying the dhikir to Allah through both sirr and jahr alone. He also should intensively avoid his illusion which can break his dhikir. He was also asked to avoid any delicious meal and drinks ${ }^{12}$.

After performing all those procedure for a quite long time and as along as making concentration (tawajjuh) to Allah, al-Sya'rāni started to feel the soul enlightenment as he looked forward so far. I happened on Rajab 17th, $931 \mathrm{H}$ (Islamic calendar), when suddenly al-Sya'rāni felt that his door of heart was widely opened and ready to receive the revelation of laduni knowledge. ${ }^{13}$

\section{The concept of al-Sya'râni Sufism Education and its components The concept of Sufism Education}

Sufism education is the one which can make people have noble characteristic, not only cognitive one but also affective one or awareness aspect.

Therefore tasawuf is not only an individual wisdom (doing mystical ritual) but also a relation to Allah and His prophet. It also sets out the piety in universal.

In some literature the terminology of Sufism education is called religious education. There are three things which should exist in religious education, especially Islamic education; first, the dimension of knowledge or 'ilm; second the dimension of awareness; and third the dimesion of behavior. ${ }^{14}$

Al-Sya'râni Sufism education is the one which mainly aims at reaching ma'rifatullah. According to al-Sya'râni this level can be passed through syuhud (testimony), and to reach the level of syuhud, can be passed through studying the

\footnotetext{
${ }^{11}$ Tanwil, At-Tasawuf Fi Misr Aban Al-Asr Al-Ušmāni, 38.

${ }^{12}$ Ibid., 39.

${ }^{13}$ Ibid., 40 .

${ }^{14}$ Abdul Munir Mulkhan, Satu Tuhan seribu tafsir (Kanisius, 2007), 81.
} 
universe, through the biological and physical material and so on, just the way the secular scientists do. Al-Sya'râni ${ }^{15}$ said: "to humiliate something from nature seems to be in contradiction with qudrah having already been given to what Allah has created".

Related to the different way of teaching Sufism education, al-Sya'râni's Sufism education teaches Syuhud (testimony) in performing the study of universe towards the existence of universe. This needs the spiritual pre-requirements, that is the purity of soul through dhikir, tafakur, reciting Quran, istighfar, and so on. It means that all things can be used as a proof of the realization of the Almighty and the Merciful Allah, to encourage the students in remembering Allah forever life and ma'rifatullah. The implementation is when the students learn physics, biology, and so on, they should do prayer well and regularly by having good character. The study of nature having been done by the secular scientist so far does not stand for syuhud even ma'rifat, but for understanding and processing the nature.

\section{The Components of Sufism Education}

The components of Sufism education cover some aspects, they are:

\section{Goal Aspects.}

The Sufism education aims at growing and increasing the students' faith which are implemented in laudably attitude so as to be progressive Moslem and to increase the faith quality by approaching the Almighty Allah.

According to al-Sya'râni the goals of Sufism education are:

1. Obtaining the Knowledge. The significance of knowledge is to rise up the moral and spiritual awareness, to encourage the faith and good deed to Allah as perfect human, to find and acknowledge Allah or ma'rifatullah.

2. Possessing good character or moral. Al-Sya'rāni ${ }^{16}$ as al-Gazâlî, said that character is deed which has been planted inside the soul and emerged at the form of deed easily without thinking and considering anything. Character is dynamic not static, intensive to direct to the advancement from bad to good, not in opposite way. That can be reached by mujāhadah and riyādah.

3. Divinity awareness. It is an important aspect of value education, especially for religious and value-based education. Danah Zohar dan Ian Marshall ${ }^{17}$ said that awareness is not direct impact from sense input, but it is intrinsically appeared

\footnotetext{
${ }^{15}$ Abdul Wahab al-Sya'rāni, Cahaya Suci Pada Pintu-Pintu Surga, Adab Bertasawuf Dalam Bingkai Syar'i (Surabaya: Risalah Gusti, 2011), 580.

${ }^{16}$ al-Sya'rāni, Al-Anwar Al-Qudsiyah Fi Ma'rifati as-Sū fiyyah, 49.

${ }^{17}$ Danah Zohar, Spiritual Intelligence: The Ultimate Intelligence (Bloomsbury Publishing, 2012), 67.
}

Teosofia: Indonesian Journal of Islamic Mysticism, Volume 5, Number 1, 2016 
and strengthened (or contextualized) by sense input. In short term, brain is created to be a tool of thinking and functions consciously. It is designed to have transcendental dimension. Human awareness is one important element on spiritual perspicacity.

\section{The Aspect of Teaching Material}

Teaching material of Sufism education covers:

1. Taghdiyah teaching material, consisting of:

a. 'Amal Dimension, which comprises of:

1. Nawāfil prayer, which is connected to five times prayer, both obligatory prayers and optional prayer. Al-Sya'rāni ${ }^{18}$ said that it is a material to approach to Allah, and someone ought to be busy with it.

2. Fasting service, to which al-Sya'rāni gives more attention in the working through fasting service on both obligatory and optional one. Obligatory service means it is the one from Allah, the implementation cannot be ignored, whereas optional service means the one to perfect obligatory one ${ }^{19}$. Kinds of optional services are: (1) Monday-Thursday Fasting, both on the location and on the way. (2) Three days Fasting (ayyām al-bīẹ), that is fasting on the date of 13,14, and 15 every Islamic month; al-Sya'rāni ${ }^{20}$ said as şaum ayyām al-bīd.

3. Giving alms service, both obligatory and optional one have service values as teaching materials in doer to be close to Allah. Optional alms are giving alms apart of zakat-firth that has already been obligated. Someone who performs tatawwu', through alms is said to love Allah and to obtain love from Allah.

4. Qanā'ah, qanā'ah is calm heart (tuma'nīnah) to obtain Allah blessing (riḍa); to make use the worldliness just necessarily to fit the needs, which is considered to be able to fulfill the obligation (syari'at), to avoid the sins. ${ }^{21}$

5. Being Patient, it is one fundamental mental attitude for Sufism. Being patient is meant to restrain (al-habs wa al-kuf) from all unwilling things due to get Allah blessing (riḍ̄a) such as calamity of death, sickness, and poverty.

\footnotetext{
${ }^{18}$ Abdul Wahab al-Sya'rāni, Lawāqị Al-Anwar Al-Qudsiyah Fi Bayāni Al-Uhud Al-Muhamadiyah, (Beirut: Dar al-Kotob al-Ilmiya, 1998), 91.

19 Ibid.

${ }^{20}$ Ibid., 92.

21 Ibid., 77.
} 
6. Zikr al-maut is remembering death, because death is a transition period between the perishable worldly life (fana') and the beyond life (baq $\bar{a}^{\prime}$ ), a period when someone will meets Allah.

7. Visiting grave, means to visit ('iyādah)22. Visiting grave or doing ziarah to someone already laid in rest or buried in cemetery. Al-Sya'rāni said that visiting gave makes a man know the destination place to go back.

8. Amar ma'ruf nahi munkar, al-Sya'rāni, ${ }^{23}$ affirming that to do amar ma'ruf is an effort to give people motivation in order to do the good and advantageous deeds for mankind physically and metaphysically.

9. Ikhlās, ikhlās is a clean heart in order to only direct to Allah in performing the observance; the heart cannot direct other than to Allah. ${ }^{24}$ Every deed has soul, whereas the soul of observance of deed is ikhlās.

10. Taqarrub, taqarrub is the closeness of a servant's heart to Allah in oder that he/she is able to witness the greatness and magnificence of Allah. When he/she looks something in the nature, his/her heart always feels something as the creation of Allah. ${ }^{25}$

b. dhikir Dimension, comprises of:

1. Dhikir is remember Allah as the One to worship the best. Someone obeys His order, keeping away from His prohibition, finding a holy way increase the ma'rifat to Allah. ${ }^{26}$ There are some levels os dhikir, they are: oral dhikir, nafs, qalb, sirr, khāfi, and akhfā al-khafi.

2. Qira'ah al-Qur'an, al-Sya'rāni ${ }^{27}$ explain that one of the ways to clean soul is reciting Quran deeply, with full and total comprehension. It is the most important dhikir because it is kalämullah and it is substantially the noblest word. ${ }^{28}$

c. Tafakur Dimension, comprises of:

1. Tafakur, Al-Sya'rāni ${ }^{29}$ said that a thinking man should look at the character, soul and parts of body by thinking deeply. Then he/she should look at all creatures of Allah so that he/she will know the creator.

\footnotetext{
${ }^{22}$ Muhammad ibn Mukarram Ibn Manẓūr, Lisān Al-'Arab. Būlāq [Edition] Al-Jirm 12 (al-Dār al-mașriyat altālīf wa-al-tarjamat, 1966), 333.

${ }^{23}$ al-Sya'rāni, Lawāqiḥ Al-Anwar Al-Qudsiyah Fi Bayāni Al-Uhud Al-Muhamadiyah, 315.

24 Ibid., 498.

${ }^{25}$ Ibid., 117.

${ }^{26}$ Ibid., 151.

${ }^{27}$ Ibid., 74.

${ }^{28}$ Ibid., 214.

${ }^{29}$ Ibid., 170.
}

Teosofia: Indonesian Journal of Islamic Mysticism, Volume 5, Number 1, 2016 
2. Ridāa riḍa is to accept widely and openly in heart towards anything from Allah, either to accept / to perform the rules of Islamic education or to relate the destiny problem. ${ }^{30}$

3. Khalwat, khalwat is one of the most effective riyaddah form and beloved by the Sufism people, because by khalwat, the direction of one's soul will be focused and accurate as well as to prepare oneself to obtain the purity and the brightness of soul, to obtain the level of ma'rifatullah.

4. 'Uzlah, 'uzlah is derived from the word 'azala which means to override. Then the meaning of 'uzlah expands to be the religious service. ${ }^{31}$ 'Uzlah, according to al-Sya'rāni (tt., Juz II: 29), is to be lone, and to be away of the tumult with mankind. It is very advantageous for the purity of a student's soul or sālik.

5. Ma'rifat, related to ma'rifatullah, al-Sya'rāni ${ }^{32}$ said that, a student (sālik), on the way to Allah SWT, has some special steps. First, a student is listening; second, understanding; third, knowing; forth, witnessing; and fifth acknowledging (ma'rifah).

The levels of ma'rifat according to Amin Syukur ${ }^{33}$ are: ma'rifatullah, ma'rifat an-nafs, ma'rifat an-nas, and ma'rifat al-kaun. 1) ma'rifatullah, as the base of the next ma'rifat. By acknowledging Allah, the man will be encouraged to comprehend His magnificence. Then, one would like to pay attention on nature and environment so he/she will be aware of fully comprehension the symbol of Allah greatness; be aware of fully understanding one's needs to develop the ecology, both milieu and environment without making the destruction. 2) ma'rifat an-nafs means recognizing oneself. 3) ma'rifat an-nas means recognizing the fellow being. The recognizing towards the fellow being is a must because it is realized that human is a social creature. In social context human has an obligation to make balance between the hereafter happiness 4) ma'rifat al-kaun means recognizing the nature.

3. The teaching material of $\operatorname{tahdh} \bar{i} \boldsymbol{b}$ (cleansing), that covers:

1. Repent and forswear, according to al-Sya'rāni is an-nadm meaning a form of regret to wrong deeds which have been performed, to re-perform the good deeds and promise not to repeat the fault.

${ }^{30}$ Ibid., 78-79.

${ }^{31}$ Manzēū, Lisān Al-’Arab, ed. 12, (Bairut: al-Dār al-Mașriyat Al-Tālīf Wa-Al-Tarjamat , 1966), 440.

${ }^{32}$ Abdul Wahab al-Sya'rāni, Lawāqịh Al-Anwar Al-Qudsiyah Fi Ma'rifati Qawāid as-Ṣūfiyah (Beirut: Dār alFikr, 1996), 168.

${ }^{33}$ M. Amin Syukur and Fathimah Usman, Terapi Hati Dalam Seni Menata Hati, Semarang: Pustaka Nuun Dan Lembkota, 2009, 13. 
2. Istighfar, a Sufism person should always make self-correction and realize all inadequacies and deformity, by stepping up istighfar to repent and forswear.

3. Wara', according to al-Sya'rāni ${ }^{34}$ means to left every syubhat and every unuseful thing, or leaving thing that is overloaded (fudul).

4. Zuhud, the meaning of zuhud is the mentality of avoiding the worldly life for the sake of hereafter life, or on the word to balance the external and internal aspects, the material and spiritual aspects. ${ }^{35}$

\section{The teacher and students aspects in Sufism education}

\section{Guru.}

Guru, according to al-Sya'rani, terminologically means mursyid. It is the one who guides the students to step to Allah by tracing the way. Through the guidamce of guru, the students step up the level beside Allah, by the mean of syariat knowledge and hakekat, strengthened by Quran and sunnah, following the track of 'ulama the heir of prophet and ulama who had been already educated by previous mursyid and got permission from the grand-guru to teach and guide the people. In Sufism education he/she is the mediator, and the student's to get wușul to Allah.

Guru efforts to raise up and grow the awareness of divinity by doing some ways, they are: multiplying the dhikir, mujâhadah, riyâdah intensively and studying the nature. Everything related to the nature is used as prove and sign of the existence of all powerful Allah and His generosity. All are to encourage the mankind (the students) to remember Allah forever, be grateful to Allah obey His orders.

\section{Murid.}

Student in Sufism education is terminologically meant sālik. Sālik means man who spiritually steps to be close to Allah to obtain His blessing (rid̄a). He/she is the one who is willing to, the one who demands. Student in literal means someone who intends and needs something by irsyad (guidance) of someone else, the one who prosecutes the knowledge. It means that the task of guru is to invite and to guide the students to acknowledge their God based on their own perspective. In other word, the effort of guru to guide and give the direction about the means of God in side their heart. In the guidance context, guru guides the practice of ritual activities and trainings which are programmed well. Based on the tradition of tassawuf it is more strategic to practically

\footnotetext{
${ }^{34}$ al-Sya'rāni, Lawāqị Al-Anwar Al-Qudsiyah Fi Bayāni Al-Uhud Al-Muhamadiyah, 75.

${ }^{35}$ al-Sya'rāni, Al-Anwar Al-Qudsiyah Fi Ma'rifati as-Șüfiyyah, 48.
} 
focus on the enrichment of the divinity experience, ritual prayer, and morals, in that the students do not only enrich the knowledge.

Nowadays context the enrichment of ritual experience could be performed by the enrichment of divinity through the history study of the successful person, being ashamed, and the fortress of evil deeds, like already done by Hoegeng Iman Santoso, discipline and honesty always become his symbol in performing his duty in everywhere. Another one is the historical study of people's failure on daily life such as the regent of Bandung city on the case of bribe on Bandung court. So, he could not continue serving the government, the level of corruption performed by the capable person of elite political party entitled Islam, related to the case of beef imported quota and money laundering. Besides, it can be through the study of nature, like physics study, biology, chemistry, which focuses on the Almighty Allah who creates the universe and all creatures from the lowest level to the energy and human being.

\section{E. The Method Aspect on the Sufism Education}

Method, according to al-Sya'rāni ${ }^{36}$ is a way or how to reach the goal, through the activities dan a human effort to increase one's personality by building the personal potentiality. In the Sufism education context, it can be understood that tariqah or the method of Sufism education to achieve the goals of teaching and learning through the activities and the human effort to build the character by developing and building one's potentiality.

The type of teaching method, whereas, are offered by as-Sya'rāni; they are; 1) method of mujāhadah and riyādah, 2) method of at-Tadrij, 3) method of al-uswah (model) and customizing, 4) method of history, and 5) method of advice.

The al-Uswah method (model) and customizing are so effective in preparing and building characters spiritually and socially because guru is example and ideal model for the children. All behavior, attitude and utterances will attach inside the student's feeling. It becomes the decisive factor on the success. The good model will be imitated and followed by the identification of good deeds values to be selected and performed. This method has a persuasive value so there will be unconsciously absorption and infection of deeds values.

\section{F. The relevance of Sufism education to character building}

From the above explanation there will be presented things related to alSya'râni Sufism education and the development of character building, they are:

\footnotetext{
${ }^{36}$ Abdul Wahab al-Sya'rāni, Beranda Sang Sufi, (Bandung: Hikmah, 2003), 51.
} 
1. Both Sufism education and character building shape good laudable.

2. Both Sufism education and character building believe in the divinity values and humanities.

3. Both Sufism education and character building have a belief that the impacts of man behaviors in the world will bring a consequence in the world and hereafter.

4. Both Sufism education and character building aim at self-building with science to be close (taqarrub) to Allah.

5. Both Sufism education and character building make use of nawâfil, dhikir, tafakur, reciting pray, and Qur'ân, as the form of taqarrub to Allah.

6. Both Sufism education and character building give priority to guru as the guide of student.

7. Both Sufism education and character building shows the student's attitude to submit and to obey the guru.

8. Both Sufism education and character building make use the method of goo model and advice in presenting the teaching material.

\section{G. Conclusion}

Objective aspect of al-Sya'râni Sufism education is an education of which its main objective is to increase the character and the awareness of divinity to reach ma'rifatullah. The level of ma'rifatullah can be reached by means of syuhud, and to reach the level of syuhud, can be reached by performing the study of nature as having been done by the secular scientist. The difference is that in doing the study of nature alSya'râni Sufism education needs the spiritual pre-requisite; that is the purity of soul which can be obtained through the teaching materials such as: dhikir, tafakur, reciting Qur'an, istighfar, and so on. It means that all things can be used as the proved and the symbols of the existence of the almighty and generosity Allah to encourage the man (the student) to remember and acknowledge Allah (ma'rifatullah) forever life in remembering, recognizing Allah, thanking to Allah and obeying all His orders. The implementation is as studying the material of physics, biology, and so on, the students should do five prayers well and regularly.

Guru is one who guides the students to go in the direction to Allah by tracing His way. According to al-Sya'râni it is called mursyid. Whereas, the student, according to alSya'rāni, is called as sālik. Sālik is person who spiritually steps forward to get close to Allah to obtain His blessings (ridā). 
The method in Sufism education is called tarīqah. It is a way or technique to reach the education and teaching objectives through the activities and human efforts in order to increase human character by guiding and developing the one's potentiality.

Al-Sya'rāni education concept and the development of character building in Indonesia have some relevant points; they are: both Sufism education and character building shape good laudable; both Sufism education and character building believe in the divinity values and humanity; both Sufism education and character building have a belief that the impacts of man behaviors in the world will bring a consequence in the world and hereafter; both Sufism education and character building aim at self-building with science to be close taqarrub) to Allah; both Sufism education and character building make use of nawâfil, dhikir, tafakur, reciting pray, and Qur'ân, as the form of taqarrub to Allah; both Sufism education and character building give priority to guru as the guide of student; both Sufism education and character building shows the student's attitude to submit and to obey the guru; both Sufism education and character building make use the method of goo model and advice in presenting the teaching material. 


\section{Bibliografy}

Azra, Azyumardi, Esei-esei intelektual Muslim dan pendidikan Islam, Jakarta: Logos

Wacana Ilmu, 1999.

Bosworth, Clifford Edmund, The Encyclopaedia of Islam, Leidien: Brill, 1997.

Kartanegara, Mulyadhi, Menyelami Lubuk Tasawuf, Jakarta: Erlangga, 2006.

Kuhn, Thomas S, Peran Paradigma Dalam Revolusi Sains, Bandung: Remadja Karya, 1989.

Manz̄ūr, Muḥammad ibn Mukarram Ibn, Lisān Al-'Arab, ed.12, Bairut: al-Dār al-Maṣriyat

Al-Tālīf Wa-Al-Tarjamat, 1966.

Mulkhan, Abdul Munir, Satu Tuhan seribu tafsir, Yogyakarta: Kanisius, 2007.

Najjar, Amir, Psikoterapi Sufistik Dalam Kehidupan Modern, Bandung: Hikmah, 2004.

Al-Sya'rāni, Abdul Wahab, Al-Anwar Al-Qudsiyah Fi Ma'rifati as-Șūfiyyah, Bairut: al-

Maktabah al-Ilmiyah, 1992.

, Beranda Sang Sufi, Bandung: Hikmah, 2003.

, Cahaya Suci Pada Pintu-Pintu Surga, Adab Bertasawuf Dalam Bingkai Syar'i,

Surabaya: Risalah Gusti, 2011. , Lawāqih Al-Anwar Al-Qudsiyah Fi Bayāni Al-Uhud Al-Muhamadiyah, Beirut:

Dar al-Kotob al-Ilmiya, 1998. Lawāqih̆ Al-Anwar Al-Qudsiyah Fi Ma'rifati Qawāid as-Șūfiyah, Beirut: Dār alFikr, 1996.

Syukur, M. Amin, and Fathimah Usman, Terapi Hati Dalam Seni Menata Hati, Semarang: Pustaka Nuun Dan Lembkota, 2009.

Tanwil, Taufiq, At-Tasawuf Fi Misr Aban Al-Asr Al-Uśmāni, Cairo: al-Hai'a al-Misriyya, n.d.

Zohar, Danah. Spiritual Intelligence: The Ultimate Intelligence, New York: Bloomsbury

Publishing, 2012. 
